\title{
AN ANALYSIS OF PRESENT STATUS OF MILK PRODUCTION IN INDIA
}

\author{
Dr. M.V. Dinesha \\ Assistant professor, DoS in Economics \& Co-operation, Manasagangothri, University of Mysore, Mysuru \\ Karnataka, India.
}

DOI: 10.46609/IJSSER.2021.v06i03.013 URL: https://doi.org/10.46609/IJSSER.2021.v06i03.013

\begin{abstract}
India is well known as the oyster of global dairy Industry. India emerged has the largest producer of milk in the world with 22.29percent share in global milk production (2018). According to National Dairy Development Board, demand for milk is expected to increase at a CGR of 5\% from 138 Million tonnes in 2014 to 200 million tonnes in 2022. Usually one or two milch animals enable the farmers to generate sufficient income to break the vicious subsistence agriculture debt cycle. Nearly 70 per cent of those earning their livelihood from milk are women. Milk and milk products are main constituents of the daily diet, especially for vulnerable groups such as infant's school age children and old age. Per capita availability of milk increased from $130 \mathrm{gms}$ per day in 1950-51 to 394gms per day in 2018-19. The annual growth rate of milk production registered 6.47 in 2018-19. Uttar Pradesh, Rajasthan, Madhya Pradesh, Andhra Pradesh and Gujarat were the top five leading states in milk. These states are contributing 53.1 percent to total milk production. Least milk producing states are Mizoram, Chandigarh, Arunachal Pradesh and Goa. There is a need of encouraging milk rearing activity in the country to support rural livelihood, sustainable agriculture practices, healthy human resource and for better global trade.
\end{abstract}

Key words: Present, Status, Milk Production

\section{Introduction}

India ranks first among the world's milk producing nations since 1998. It also has the largest milk producing animal population of over 187 million. India is well known as the oyster of global dairy Industry. Milk production in India increased from 17 million tonnes (MT) in 195051 to 187.96 million tonnes in 2018-19. India accounts for around $22.29 \%$ of world's dairy production. According to National Dairy Development Board demand for milk is expected to increase at a CGR of 5\% from 138 Million tonnes in 2014 to 200 million tonnes in 2022. As per 


\section{International Journal of Social Science and Economic Research}

ISSN: $2455-8834$

Volume:06, Issue:03 "March 2021"

Economic survey statistics the per capita availability of milk in the country was 130 grams per day during 1950-51, it increased to 394 grams per day in 2018-19.

In India milk production is dominated by marginal and small landholding farmers and also by landless labourers who are in aggregate $71 \%$ of the national milk animal herd. Dairying is a subsidiary source of income and occupation. It is real relief to most of the farmers in the society. Usually one or two milch animals enable the farmers to generate sufficient income to break the vicious subsistence agriculture debt cycle. Nearly 70 per cent of those earning their livelihood from milk are women. Milk is one of the few commodities which give the producer a large share of what the consumer pays for it. The value of milk is more than that or rice and wheat combined. As per National Account Statistics 2019, the value of output of milk in 2017-18 is Rs $7,01,530$ crore (at current price) surpassing total value of output from the top two food grains Rs 27,22,21 crore (paddy) and Rs 1,73,984 crore (wheat).

In the total milk production, about $48 \%$ of milk is consumed at the producer level or sold to nonproducers in the rural area. Remaining $52 \%$ of the milk is marketable surplus available for sale to consumers in urban areas. Out of marketable surplus it is estimated that about 40 per cent of the milk sold is handled by the organized sector (i.e. 20percent each by Co-operative \& Private Dairies) and the remaining 60 percent by the unorganized sector. About 16.6 million farmers have been brought under the ambit of about 1, 85,903 village level Dairy Co-operative Societies (DCS) up to March 2018. Despite the slump in world market and better procurement prices by dairy cooperatives along with decrease in procurement volume by major private players led to increase in milk collection by the dairy cooperatives by about $11 \%$. The dairy cooperatives have procured daily average of milk about 475.6 Lakh Kg per day (LKgPD) during 2017-18 as compared to 428.7 lakh $\mathrm{kg}$ procured during 2016-17. The sale of liquid milk reached to 349.6 Lakh Litre per day (LLPD) during 2017-18 recording a growth of 6 percent as compared to 331 LLPD marketed during 2016-17. Women members of the DCS are also being encouraged to assume leadership roles. As on March 2018, the total number of women in dairy cooperatives across the country was 32,092 which is $29.5 \%$ of total farmers.

Milk is the nature's perfect food for human. Milk comprises of 87 per cent water and 13 per cent solid. It is considered as a nearly complete food since it is a good source of protein, fat and major minerals. No other single food can substitute for milk in diet and give a person the same nutrients that you get from a glass of milk. Milk and milk products are main constituents of the daily diet, especially for vulnerable groups such as infant's school age children and old age. Milk is one of the most important nutrition food sources besides breast milk for infants and babies. In fact, consumption of dairy products has recently been linked to health benefits that are the direct antitheses of diseases and complexity that related to overweight and obesity. 
International Journal of Social Science and Economic Research

ISSN: 2455-8834

Volume:06, Issue:03 "March 2021"

\section{Objectives of the study}

The main objectives of this research paper are as follows.

1. To study the trends of milk production in India

2. To examine the state wise milk production in India

\section{Database and Research Methodology}

This research paper is based on secondary data. It has collected from Basic Animal Husbandry Statistics, Ministry of Agriculture, Government of India, National Dairy Development Board, Government of India, India stats and various reports of Reserve Bank of India. Statistical tools like Annual growth rate, Exponential growth model, Dummy variable model and one way Anova model were used to analyse data.

\section{Status of Milk Production in the World}

The following table 1 represents the top ten milk producing countries of the world. In 1970, USA stand first place in milk production followed by Germany, France, India, UK, Pakistan, Brazil, Newzealand, China and Russia. During 2018, India emerged has the largest milk producer in the world, USA and Pakistan were in second and third place respectively. In the global milk production 843.04 Million Tonnes, India's share is $187.96 \mathrm{MT}$, USA share is 98.72MT and Pakistan with 45.79MT.

Price support measure given by the government and the rising domestic demand for value added products, cross breed technology, huge investment by MNC's, efficient resource use, assistance to co-operatives, Dairy Entrepreneurship Development Scheme and innovative technologies adopted in production and processing were responsible for rise in production of milk in India.

Table 1: Milk Production of Top Ten Countries in the world (1970 to 2018)

\begin{tabular}{|c|c|c|c|c|c|c|c|c|c|c|c|c|}
\hline $\begin{array}{c}\text { Countries / } \\
\text { Years }\end{array}$ & 1970 & 1975 & 1980 & 1985 & 1990 & 1995 & 2000 & 2005 & 2010 & 2015 & 2018 & $\begin{array}{c}\text { Ranking } \\
\text { in } 2018\end{array}$ \\
\hline India & 20.80 & 25.60 & 31.56 & 44.02 & 53.68 & 65.37 & 79.66 & 95.62 & 121.85 & 155.69 & 187.96 & 1 \\
\hline USA & 53.07 & 52.34 & 58.24 & 64.93 & 67.01 & 70.46 & 75.95 & 80.28 & 87.52 & 94.64 & 98.72 & 2 \\
\hline Pakistan & 7.45 & 8.19 & 9.01 & 10.86 & 14.72 & 19.01 & 25.57 & 29.44 & 35.49 & 41.59 & 45.79 & 3 \\
\hline China & 1.96 & 2.37 & 2.93 & 4.76 & 7.04 & 9.46 & 12.37 & 32.02 & 41.16 & 36.28 & 35.60 & 4 \\
\hline Brazil & 7.42 & 10.05 & 12.06 & 12.57 & 15.08 & 17.13 & 20.53 & 25.53 & 30.96 & 34.86 & 34.11 & 5 \\
\hline Germany & 28.18 & 28.75 & 32.10 & 33.63 & 31.34 & 28.63 & 28.35 & 28.48 & 29.65 & 32.71 & 33.09 & 6 \\
\hline Russia & 0.00 & 0.00 & 0.00 & 0.00 & 0.00 & 39.31 & 32.28 & 31.15 & 31.84 & 30.79 & 30.61 & 7 \\
\hline France & 22.85 & 24.72 & 27.89 & 28.40 & 26.81 & 26.09 & 25.74 & 25.71 & 24.21 & 25.93 & 26.52 & 8 \\
\hline New Zealand & 5.99 & 6.10 & 6.70 & 7.88 & 7.51 & 9.29 & 12.24 & 14.64 & 17.01 & 21.94 & 21.39 & 9 \\
\hline UK & 12.97 & 13.93 & 15.97 & 16.02 & 15.25 & 14.84 & 14.49 & 14.47 & 14.07 & 15.32 & 15.31 & 10 \\
\hline World & 391.95 & 424.73 & 465.82 & 512.98 & 542.47 & 540.00 & 579.51 & 649.76 & 723.55 & 801.69 & 843.04 & \\
\hline
\end{tabular}

Source: Data compiled from NDDB Report, Basic Animal Husbandry Statistics and India Stats.com 
International Journal of Social Science and Economic Research

ISSN: 2455-8834

Volume:06, Issue:03 "March 2021"

Figure: 1 Global Ranking of Milk Production (2018)

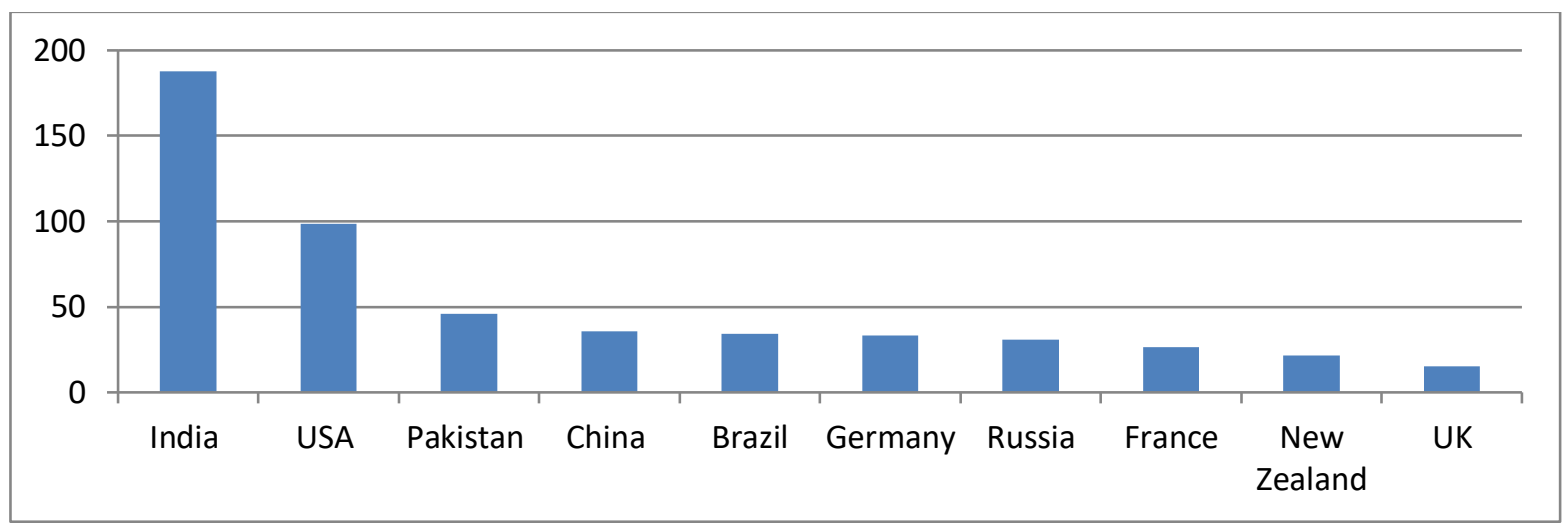

The above figure 1 indicates top ten milk producing countries of the world in 2018. India stand first place followed by USA, Pakistan, China, Brazil, Germany, Russia, France, New Zealand and UK.

Table 2: Percentage Share of India in Global Milk Production (1970 to 2018)

\begin{tabular}{|c|c|c|c|}
\hline Year & $\begin{array}{c}\text { Global } \\
\text { Milk } \\
\text { Production }\end{array}$ & $\begin{array}{c}\text { India's } \\
\text { Milk } \\
\text { Production }\end{array}$ & $\begin{array}{c}\text { \% Share of } \\
\text { India in } \\
\text { global milk } \\
\text { production }\end{array}$ \\
\hline 1970 & $\mathbf{3 9 1 . 9 5}$ & 20.80 & 5.30 \\
\hline 1975 & $\mathbf{4 2 4 . 7 3}$ & 25.60 & 6.02 \\
\hline 1980 & $\mathbf{4 6 5 . 8 2}$ & 31.56 & 6.77 \\
\hline 1985 & $\mathbf{5 1 2 . 9 8}$ & 44.02 & 8.58 \\
\hline 1990 & $\mathbf{5 4 2 . 4 7}$ & 53.68 & 9.89 \\
\hline 1995 & $\mathbf{5 4 0 . 0 0}$ & 65.37 & 12.1 \\
\hline 2000 & $\mathbf{5 7 9 . 5 1}$ & 79.66 & 13.74 \\
\hline 2005 & $\mathbf{6 4 9 . 7 6}$ & 95.62 & 14.71 \\
\hline 2010 & $\mathbf{7 2 3 . 5 5}$ & 121.85 & 16.84 \\
\hline 2015 & $\mathbf{8 0 1 . 6 9}$ & 155.69 & 19.42 \\
\hline 2018 & $\mathbf{8 4 3 . 0 4}$ & 187.96 & 22.29 \\
\hline
\end{tabular}

Source: Basic Animal Husbandry Statistics 
International Journal of Social Science and Economic Research

ISSN: 2455-8834

Volume:06, Issue:03 "March 2021"

Figure 2: India's Percentage Share in Global Milk Production

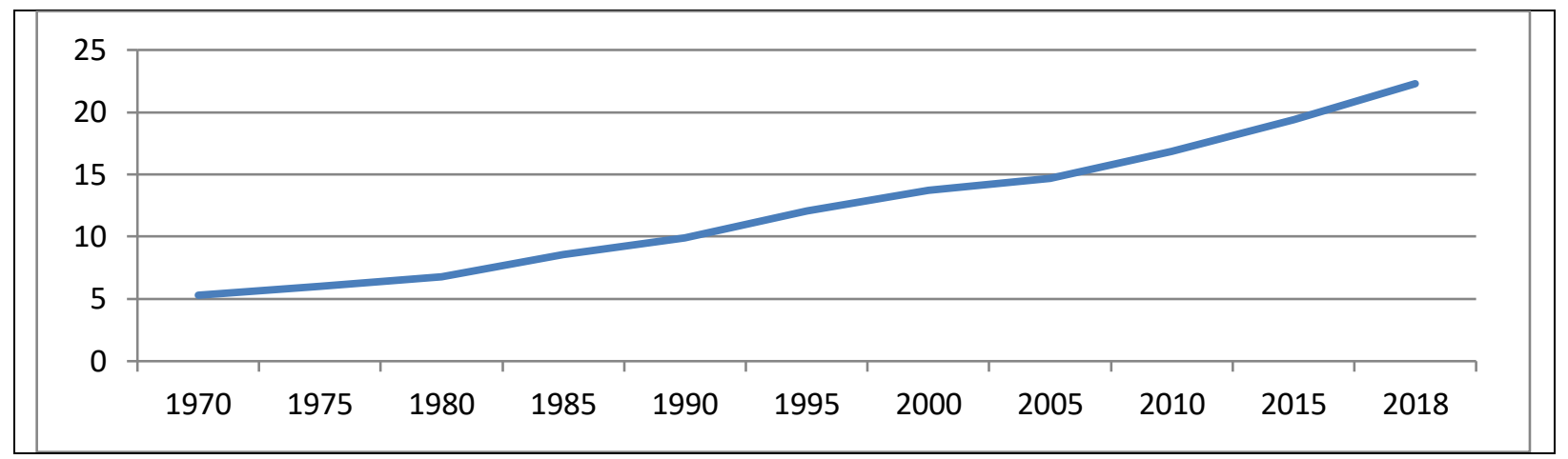

Table 2 and graph 2 reveals percentage share of India in global milk production. In 1970 global milk production was 391.95MT in which India's share was 20.80MT i.e., 5.30percent. During the time of new economic policy1990, India's share in global milk production reached 9.89percent and rose significantly to 16.84 percent in 2010. In 2018, India emerged has the largest producer of milk in the world with 22.29percent share in global milk production.

Table 3: Composition of Milk in India from 2000-01 to 2018-19 (Milk production in tonnes)

\begin{tabular}{|c|c|c|c|c|}
\hline Year & Cow Milk & $\begin{array}{c}\text { Buffaloes } \\
\text { Milk }\end{array}$ & $\begin{array}{c}\text { Goat } \\
\text { Milk }\end{array}$ & Total \\
\hline $2000-01$ & 32957.00 & 43428.00 & 3266.00 & 79651.00 \\
\hline $2001-02$ & 34516.00 & 45402.00 & 3501.00 & 83419.00 \\
\hline $2002-03$ & 34612.00 & 46512.00 & 3636.00 & 84760.00 \\
\hline $2003-04$ & 34973.00 & 47979.00 & 3708.00 & 86660.00 \\
\hline $2004-05$ & 37344.00 & 50178.00 & 3537.00 & 91059.00 \\
\hline $2005-06$ & 39759.00 & 52070.00 & 3790.00 & 95619.00 \\
\hline $2006-07$ & 41148.00 & 54382.00 & 3818.00 & 99348.00 \\
\hline $2007-08$ & 46822.00 & 56630.00 & 4481.00 & 107933.00 \\
\hline $2008-09$ & 49810.00 & 57895.00 & 4478.00 & 112183.00 \\
\hline $2009-10$ & 52200.00 & 59758.00 & 4467.00 & 116425.00 \\
\hline $2010-11$ & 54903.00 & 62350.00 & 4594.00 & 121847.00 \\
\hline $2011-12$ & 57770.00 & 65352.00 & 4782.00 & 127904.00 \\
\hline $2013-14$ & 62195.00 & 70443.00 & 5048.00 & 137686.00 \\
\hline $2014-15$ & 66423.00 & 74710.00 & 5180.00 & 146314.00 \\
\hline $2015-16$ & 73646.00 & 76459.00 & 5378.00 & 155482.00 \\
\hline $2016-17$ & 78099.00 & 81266.00 & 5752.00 & 165404.00 \\
\hline $2017-18$ & 83633.57 & 86261.68 & 5789.00 & 176030.00 \\
\hline $2018-19$ & 89833.59 & 91817.14 & 5890.00 & 187000.00 \\
\hline
\end{tabular}

Source: India Stats.com 
International Journal of Social Science and Economic Research

ISSN: 2455-8834

Volume:06, Issue:03 "March 2021"

Figure 3: Composition of Milk in India

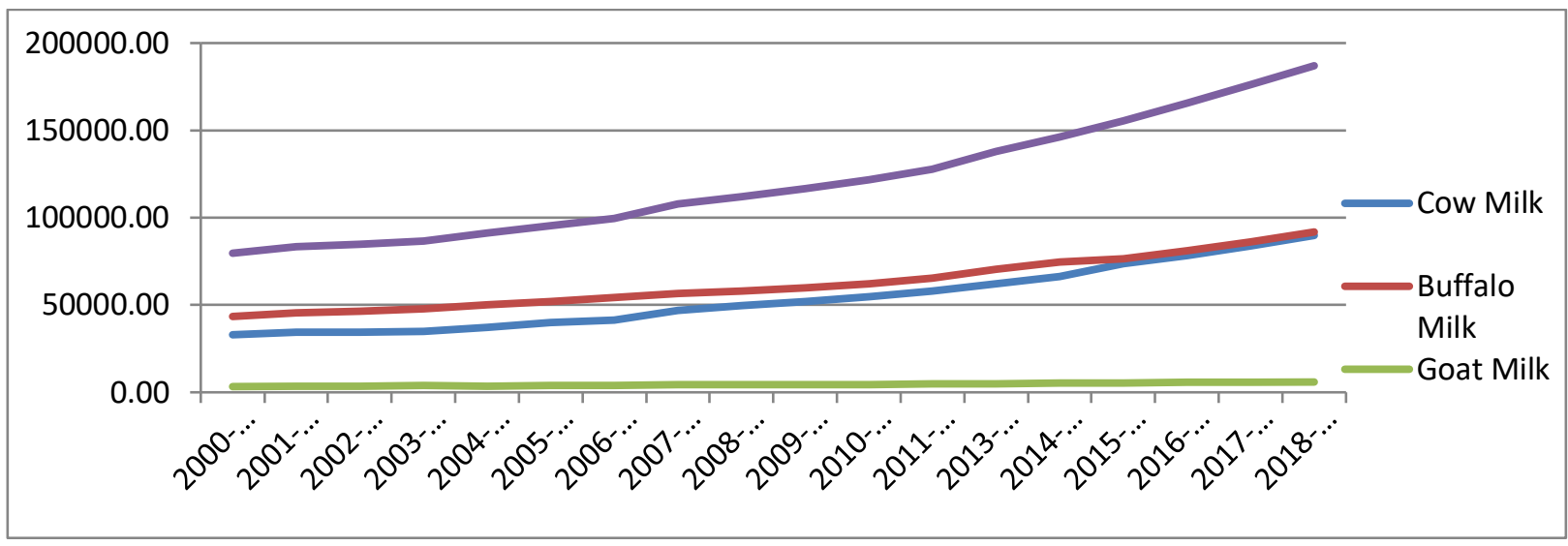

Milk is mainly contributed by cows, buffaloes and goats. Data in the table 3 represents composition of milk from cows, buffaloes and goats from 2000-01 to 2018-19. Buffaloes stand first place, cows and goats are in second and third place respectively in contributing towards total milk production.

The data in the above table reveals that cow's milk production has increased significantly from 2000-01 to 2018-19. In 2000-01 cows' milk production was 32957tonnes which increased to 54903tonnes in 2010-11. After 2010-11, there has been a significant increase in cow's milk production. It rose from 57770 tonnes in 2011-12 to 89833.59 tonnes in 2018-19.

Buffaloes are contributing more in total milk production. In 2000-01 total buffaloes milk production was 43428tonnes which increased to 62350 tonnes in 2010-11. After 2011-12 there has been a steady increase in milk production of buffaloes. It rose from 65352tonnes in 201112 to 91817.14 tones to $2018-19$.

Goat's contribution is least in total milk production. During 2000-01, goats' milk production was 3266tonnes and reached 3708 tonnes in 2003-04. But production declined to 3507 tonnes in 2004-05. After this period there has been a slow growth rate of goat's milk production. It increased from 3790tonnes in 2005-06 to 5890tonnes in 2018-19.

To estimate the average growth of composition of milk production in India for the study period, Exponential Growth Model has been used. 
International Journal of Social Science and Economic Research

ISSN: 2455-8834

Volume:06, Issue:03 "March 2021"

Table 4: Results of Exponential Growth Model for Composition of Milk Production

\begin{tabular}{|c|c|c|c|c|}
\hline $\begin{array}{c}\text { Milk } \\
\text { Production }\end{array}$ & Growth rate & $\mathbf{t}$ & P Value & $\mathbf{R}^{\mathbf{2}}$ \\
\hline Cow & 0.062 & 33.421 & 0.000 & 0.986 \\
\hline Buffaloes & 0.043 & 37.310 & 0.000 & 0.989 \\
\hline Goat & 0.035 & 23.189 & 0.000 & 0.971 \\
\hline
\end{tabular}

The result reveals that, the average growth in cow milk production is about 6.2 per cent per year and the $P$ value is 0.000 and it is statistically significant at 1 percent level. The estimated value of the $\mathrm{R}^{2}$ for the model is 0.986 , which implies that the model is best fitted to the data.

The results of average growth of buffaloes milk production represents that, its average growth of production is about 4.3 percent per year and the $\mathrm{P}$ value is 0.000 which is also statistically significant at 1 per cent level. The estimated value of $\mathrm{R}^{2}$ for the model is 0.989 , which implies that the estimated model is best fitted to the data.

In case of goat milk production, average growth of production is about 3.5 percent per anumn and $P$ value is 0.000 , which is also statistically significant at 1 percent level. The estimated value of $\mathrm{R}^{2}$ for the model is 0.971 , which reflects that the model fitted to the data is good.

From the above results it is observed that composition of milk production has significantly increased.

Table 5: Production, Per Capita Availability, Annual Growth Rate of Milk Production and Per Capita Availability in India (1981-82 to 2018-19)

\begin{tabular}{|c|c|c|c|c|c|}
\hline Year & $\begin{array}{c}\text { Milk } \\
\text { Production } \\
\text { (Million } \\
\text { Tonnes) }\end{array}$ & $\begin{array}{c}\text { Human } \\
\text { Population } \\
\text { (in Million) }\end{array}$ & $\begin{array}{c}\text { Per Capita } \\
\text { Availability } \\
\text { (in Grams) }\end{array}$ & $\begin{array}{l}\text { AGR of Milk } \\
\text { Production } \\
\quad \text { (in \%) }\end{array}$ & $\begin{array}{c}\text { AGR of Per } \\
\text { capita availability } \\
\text { (in \%) }\end{array}$ \\
\hline 1981-1982 & 34.3 & 692 & 136 & -- & -- \\
\hline 1982-1983 & 35.8 & 708 & 139 & $4.37 \%$ & $2.21 \%$ \\
\hline $1983-1984$ & 38.8 & 723 & 147 & $8.38 \%$ & $5.76 \%$ \\
\hline 1984-1985 & 41.5 & 739 & 154 & $6.96 \%$ & $4.76 \%$ \\
\hline 1985-1986 & 44.0 & 755 & 160 & $6.02 \%$ & $3.90 \%$ \\
\hline 1986-1987 & 46.1 & 771 & 164 & $4.77 \%$ & $2.50 \%$ \\
\hline 1987-1988 & 46.7 & 788 & 162 & $1.30 \%$ & $-1.22 \%$ \\
\hline 1988-1989 & 48.4 & 805 & 165 & $3.64 \%$ & $1.85 \%$ \\
\hline 1989-1990 & 51.4 & 822 & 171 & $6.20 \%$ & $3.64 \%$ \\
\hline 1990-1991 & 53.9 & 839 & 176 & $4.86 \%$ & $2.92 \%$ \\
\hline 1991-1992 & 55.7 & 856 & 178 & $3.34 \%$ & $1.14 \%$ \\
\hline 1992-1993 & 58.0 & 872 & 182 & $4.13 \%$ & $2.25 \%$ \\
\hline 1993-1994 & 60.6 & 892 & 186 & $4.48 \%$ & $2.20 \%$ \\
\hline 1994-1995 & 63.8 & 910 & 192 & $5.28 \%$ & $3.23 \%$ \\
\hline 1995-1996 & 66.2 & 928 & 195 & $3.76 \%$ & $1.56 \%$ \\
\hline 1996-1997 & 69.1 & 946 & 200 & $4.38 \%$ & $2.56 \%$ \\
\hline 1997-1998 & 72.1 & 964 & 205 & $4.34 \%$ & $2.50 \%$ \\
\hline 1998-1999 & 75.4 & 983 & 210 & $4.58 \%$ & $2.44 \%$ \\
\hline
\end{tabular}




\section{International Journal of Social Science and Economic Research}

ISSN: 2455-8834

Volume:06, Issue:03 "March 2021"

\begin{tabular}{|l|l|l|l|l|l|}
\hline $1999-2000$ & 78.3 & 1001 & 214 & $3.85 \%$ & $1.90 \%$ \\
\hline $2000-2001$ & 80.6 & 1019 & 217 & $2.94 \%$ & $1.40 \%$ \\
\hline $2001-2002$ & 84.4 & 1040 & 222 & $4.71 \%$ & $2.30 \%$ \\
\hline $2002-2003$ & 86.2 & 1056 & 224 & $2.13 \%$ & $0.90 \%$ \\
\hline $2003-2004$ & 88.1 & 1072 & 225 & $2.20 \%$ & $0.45 \%$ \\
\hline $2004-2005$ & 92.5 & 1089 & 233 & $4.99 \%$ & $3.56 \%$ \\
\hline $2005-2006$ & 97.1 & 1106 & 241 & $4.97 \%$ & $3.43 \%$ \\
\hline $2006-2007$ & 102.6 & 1122 & 251 & $5.66 \%$ & $4.15 \%$ \\
\hline $2007-2008$ & 107.9 & 1138 & 260 & $5.17 \%$ & $3.59 \%$ \\
\hline $2008-2009$ & 112.2 & 1154 & 266 & $3.99 \%$ & $2.31 \%$ \\
\hline $2009-2010$ & 116.4 & 1170 & 273 & $3.74 \%$ & $2.63 \%$ \\
\hline $2010-2011$ & 121.8 & 1186 & 281 & $4.64 \%$ & $2.93 \%$ \\
\hline $2011-2012$ & 127.9 & 1210 & 290 & $5.01 \%$ & $3.20 \%$ \\
\hline $2012-2013$ & 132.4 & 1212 & 299 & $3.52 \%$ & $3.10 \%$ \\
\hline $2013-2014$ & 137.7 & 1228 & 307 & $4.00 \%$ & $2.68 \%$ \\
\hline $2014-2015$ & 146.3 & 1244 & 322 & $6.25 \%$ & $4.89 \%$ \\
\hline $2015-2016$ & 155.5 & 1260 & 337 & $6.29 \%$ & $4.66 \%$ \\
\hline $2016-2017$ & 165.4 & 1275 & 355 & $6.37 \%$ & $5.34 \%$ \\
\hline $2017-2018$ & 176.3 & 1290 & 375 & $6.59 \%$ & $5.63 \%$ \\
\hline $2018-2019$ & 187.7 & 1305 & 394 & $6.47 \%$ & $5.07 \%$ \\
\hline
\end{tabular}

Figure 4: Production and Per Capita Availability of Milk Production in India (1981-82 to 2018-19)

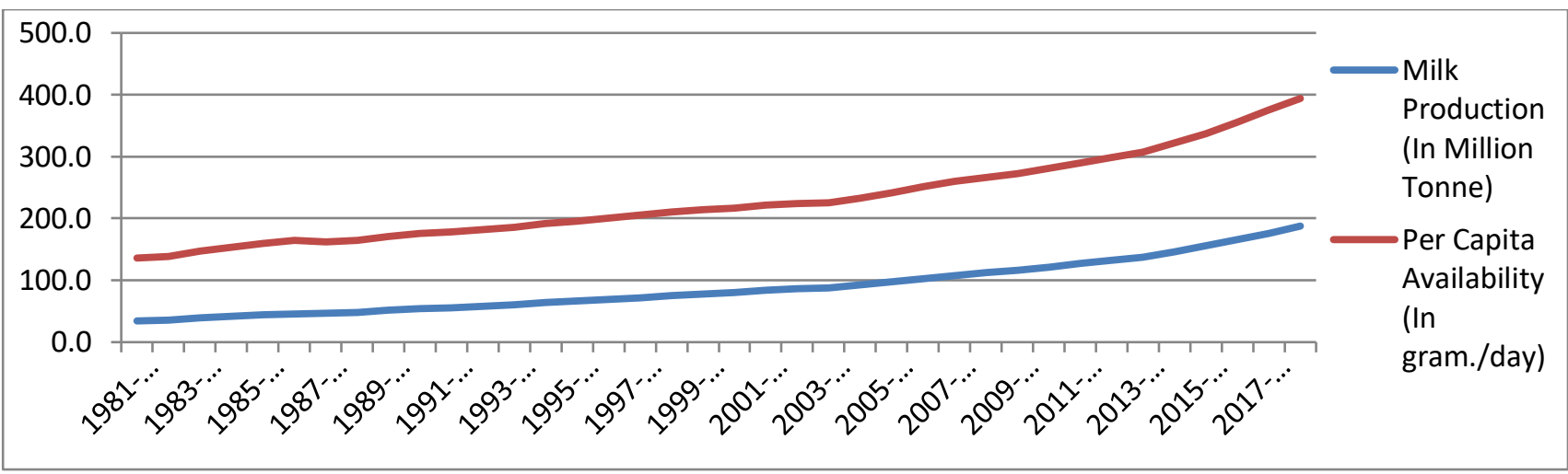

A trend showing the increase in milk production over the past few decades is depicted in the graph 4. The graph shows that, there is a consistent increase in milk production over the years. Milk production increased from 34.3 MT (million tones) in 1981-82 to 51.4MT in 1989-90. It has reached 72.1MT in 1997-98. After 1997-98 milk production has started to rise significantly. Milk production has increased from $75.4 \mathrm{MT} 1998-99$ to $80.6 \mathrm{MT}$ in 2000-01. After 2001-02, milk production rose to $116.4 \mathrm{MT}$ in $2009-10$. Since $2010-11$ there has been a significant rise in milk production. It rose from $121.8 \mathrm{MT}$ in $2010-11$ to $187.7 \mathrm{MT}$ in $2018-19$. Not only the production of milk has increased, per capita availability of milk has also increased. It was $136 \mathrm{gms}$ (grams) per day in 1981-82 and increased to 217gms per day in 2000-01. Since 2010-11 per capita availability of milk increased significantly. The per capita availability increased from 
International Journal of Social Science and Economic Research

ISSN: 2455-8834

Volume:06, Issue:03 "March 2021"

281gms per day in 2010-11 and to 394gms per day in 2018-19. This is higher than the world average and higher than $220 \mathrm{gms}$ recommended by Indian council of Medical Research.

Figure 4.1: Annual Growth Rate of Milk Production and Per Capita Availability of Milk in India (1981-82 to 2018-19)

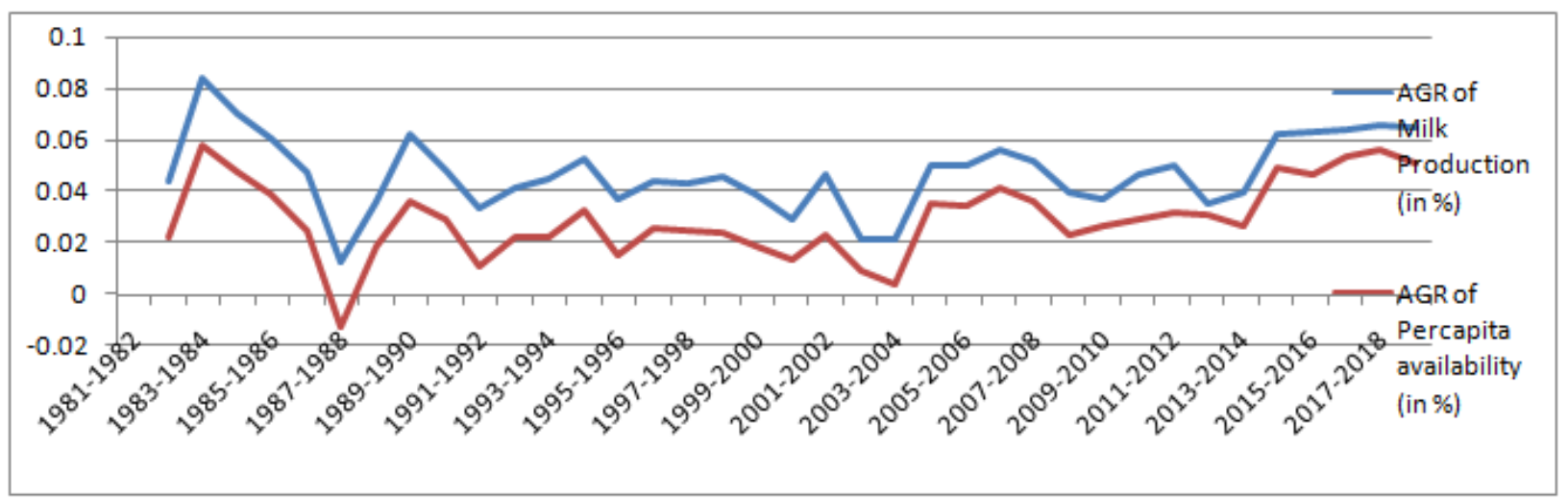

The above diagram 4.1 represents annual growth rate of milk production and per capita availability of milk in India from 1981-82 to 2018-19. The annual growth rate of milk production was 4.37per cent in 1981-82 and it declined to 1.30 per cent in 1989-90. But the annual growth rate of per capita availability increased from 2.21 per cent in 1982-83 to 5.76 percent in 1983-84. It reached negative -1.22 percent in 1987-88. After 1987-88, the annual growth rate of milk production and per capita availability were started to rise significantly. The annual growth rate of milk production has rose from 3.64 percent in 1988-89 to 6.47 percent in 2018-19. Per capita availability annual growth rate has also increased from 1.85 per cent in 1988-89 to 5.07 percent in 2018-19.

Dummy variable model is used to analyse whether milk production in India has increased significantly after 1998 or not. The results of Dummy variable model are presented below.

Table 6: Results of Dummy Variable Model for Milk Production

\begin{tabular}{|c|c|c|c|c|}
\hline Variable & Coefficient & Std. Error & T value & P. value \\
\hline $\begin{array}{l}\text { Constant } \\
\text { Time Dummy } \\
\text { No. of observation } \\
\text { (years) }=38\end{array}$ & $\begin{array}{l}43.700 \\
74.048\end{array}$ & $\begin{array}{l}5.321 \\
7.788\end{array}$ & $\begin{array}{l}8.213 \\
9.507\end{array}$ & $\begin{array}{l}0.000 \\
0.000\end{array}$ \\
\hline$R^{2}=0.678$ & \multicolumn{2}{|l|}{ F. Value $=90.389$} & \multicolumn{2}{|c|}{ Sig P. Value $=0.000$} \\
\hline
\end{tabular}


International Journal of Social Science and Economic Research

ISSN: 2455-8834

Volume:06, Issue:03 "March 2021"

Results of Dummy Variable shows that the comparison of milk production between two periods namely before and after 1998. The estimated coefficient of time dummy is positive with a value of 74.048, which implies that the milk production after 1998 has been increased on the average annually by an amount of 74.048 million tonnes. F value is 90.389 and $\mathrm{P}$ value is 0.000 . It is statistically significant at 1percent level. It implies that milk production in India has significantly increased after 1998. Adopting new methods of cattle, changing composition of feed ingredients, increase in number of dairy co-operatives and successful implementation of the white revolution were the factors responsible for rise in milk production after 1998 in India.

\section{State wise analysis of Milk production in India}

Milk is produced in almost all the states and union territories of India. As per Animal husbandry statistics report 2019, Uttar Pradesh is the largest producer of milk with 16.3per cent share in the total milk production in the country, followed by Rajasthan with a share of 12.6percent in total milk production. Madhya Pradesh stands third place with a share of 8.5percent, Andhra Pradesh (includes Telangana) and Gujarat share were 8percent and 7.7 percent stands fourth and fifth place respectively. Punjab, Maharashtra, Haryana, Bihar, Tamil Nadu and Karnataka had made significant progress in the production of milk. The least milk producing states are Mizoram, Chandigarh, Arunachal Pradesh and Goa. Union territories contribution to milk production is less than one percent. Puducherry share is 0.02 percent and Daman and Diu share is the least in total production.

To analyse the state wise production of milk, twenty states were selected and classified as south region, north region, west region and East region.

\section{Milk Production in Southern States}

Among southern states, four states were selected for the study and analysed data from 2012-13to 2018-19. Andhra Pradesh has produced 12761.65 thousand tonnes of milk in 2012-13, which increased to 15044.37 thousand tonnes in 2018-19. It is the largest producer of milk in the south region. Tamil Nadu and Karnataka were in second and third place respectively. From the data it is clear that there is a continuous increase in milk production in these two states. Kerala is the least producer of milk in the southern region. Its production of milk declined from 2790.58 thousand tonnes in 2012-13 to 2548.28 thousand tonnes in 2018-19. 
International Journal of Social Science and Economic Research

ISSN: 2455-8834

Volume:06, Issue:03 "March 2021"

Table 7: Milk Production in Southern States during 2012-13 to 2018-19 (figures in 000 tonnes)

\begin{tabular}{|l|c|c|c|c|c|c|c|}
\hline $\begin{array}{l}\text { South } \\
\text { Region }\end{array}$ & $\mathbf{2 0 1 2 - 1 3}$ & $\mathbf{2 0 1 3 - 1 4}$ & $\mathbf{2 0 1 4 - 1 5}$ & $\mathbf{2 0 1 5 - 1 6}$ & $\mathbf{2 0 1 6 - 1 7}$ & $\mathbf{2 0 1 7 - 1 8}$ & $\mathbf{2 0 1 8 - 1 9}$ \\
\hline $\begin{array}{l}\text { Andhra } \\
\text { Pradesh }\end{array}$ & 12761.65 & 13007.08 & 9656.15 & 10816.99 & 12177.94 & 13724.99 & 15044.37 \\
\hline Karnataka & 5718.22 & 5997.03 & 6120.93 & 6344.01 & 6562.15 & 7136.66 & 7900.63 \\
\hline Kerala & 2790.58 & 2654.7 & 2711.13 & 2649.82 & 2520.34 & 2575.98 & 2548.28 \\
\hline Tamil Nadu & 7004.73 & 7049.19 & 7132.47 & 7243.53 & 7556.35 & 7741.82 & 8361.68 \\
\hline
\end{tabular}

Source: India Stats.com

Figure 5: Milk Production in Southern States during 2012-13 to 2018-19 (figures in 000 tonnes)

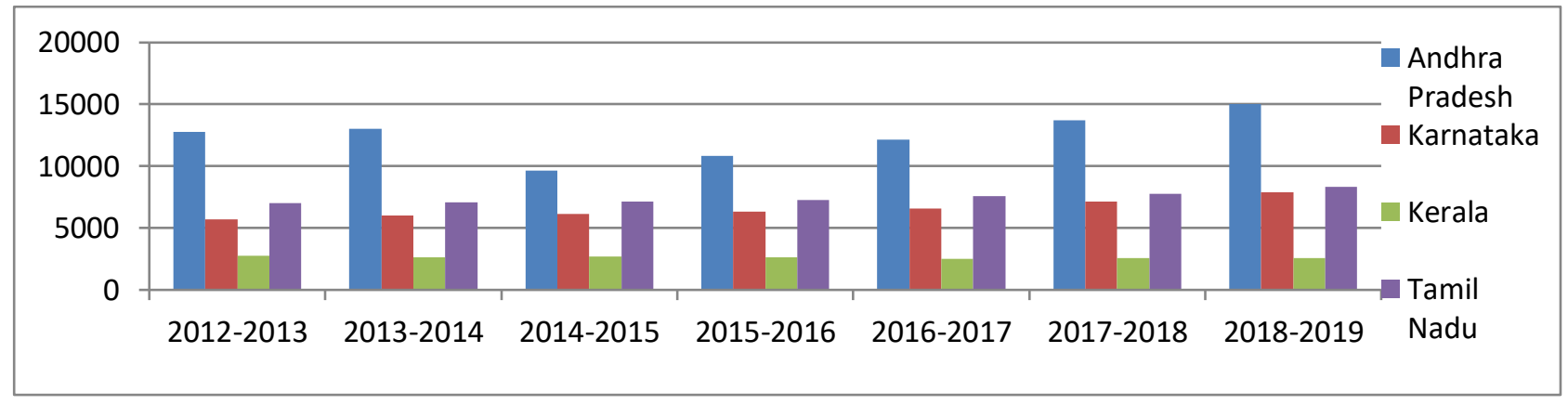

\section{Milk Production in Northern States}

In the north region, six states were chosen for the study and analysed data from 2012-13 to 201718. It is observed from the data in the table 8 , that

Table 8: Milk Production in Northern States from 2012-13 to 2018-19 (figures in 000 tonnes)

\begin{tabular}{|l|c|c|c|c|c|c|r|}
\hline North Region & $\mathbf{2 0 1 2 - 1 3}$ & $\mathbf{2 0 1 3 - 1 4}$ & $\mathbf{2 0 1 4 - 1 5}$ & $\mathbf{2 0 1 5 - 1 6}$ & $\mathbf{2 0 1 6 - 1 7}$ & $\mathbf{2 0 1 7 - 1 8}$ & $\mathbf{2 0 1 8 - 1 9}$ \\
\hline Haryana & 7040.24 & 7441.67 & 7901.35 & 8381.33 & 8974.75 & 9809 & 10726.09 \\
\hline Himachal Pradesh & 1138.6 & 1150.81 & 1172.16 & 1282.86 & 1329.11 & 1392.18 & 1460.15 \\
\hline Jammu and Kashmir & 1630.56 & 1614.67 & 1950.93 & 2273.35 & 2376.09 & 2459.79 & 2540.11 \\
\hline Punjab & 9724.34 & 10011.1 & 10351.41 & 10774.2 & 11282.06 & 11854.88 & 12598.82 \\
\hline Rajasthan & 13945.92 & 14573.05 & 16934.31 & 18500.08 & 20849.59 & 22427.1 & 23668.07 \\
\hline Uttar Pradesh & 23329.55 & 24193.9 & 25198.36 & 26386.81 & 27769.74 & 29051.72 & 30518.91 \\
\hline
\end{tabular}

Source: India Stats.com 
International Journal of Social Science and Economic Research

ISSN: 2455-8834

Volume:06, Issue:03 "March 2021"

\section{Figure 6: Milk Production in Northern States from 2012-13 to 2018-19 (figures in 000 tonnes)}

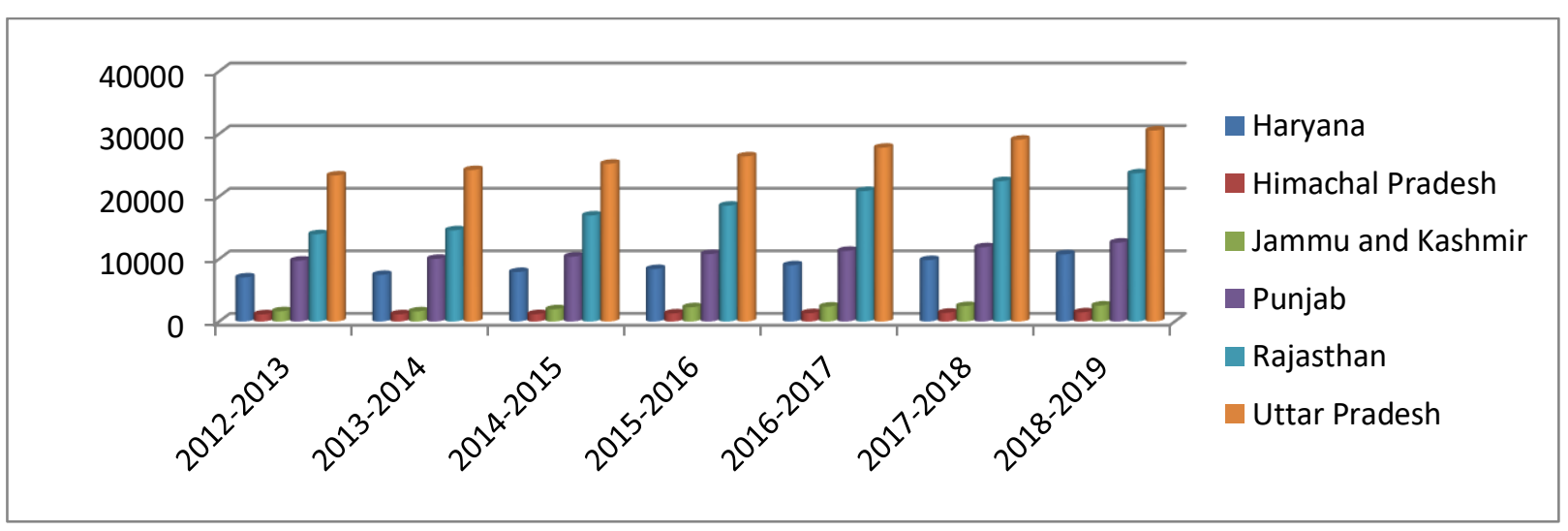

Uttar Pradesh the largest producer of milk among northern states. Its production has increased significantly from23329.55 thousand tonnes in 2012-13 to 30518.91 thousand tonnes in 2018-19. Rajasthan is the second largest producer of milk in northern region with a production of 23668.07thousand tonnes in 2018-19. Himachal Pradesh the least producer of milk in northern region. Its production has increased slowly from 1138.6 thousand tonnes in 2012-13 to 1460.15thousand tonnes in 2018-19.

\section{Milk Production in Western states}

The following table 9 and diagram 7 represents the production of milk in major states of western region. Among western states, Madhya Pradesh is the leading producer of milk. Its production has increased significantly from 8837.79 thousand tonnes n 2012-13 to 15911.13 thousand tonnes in 2018-19. Gujarat stands second place in western region. Its production has increased from 10314.63 thousand tonnes in 2012-13 to 14492.77 thousand tonnes in 2018-19. Goa is the least producer of milk in the western region. Its production has declined from 61.24 thousand tonnes in 2012-13 to 57.17 thousand tonnes in 2018-19.

Table 9: Milk Production in Western States from 2012-13 to 2018-19 (figures in 000 tonnes)

\begin{tabular}{|c|c|c|c|c|c|c|c|}
\hline West Region & $\mathbf{2 0 1 2 - 1 3}$ & $\mathbf{2 0 1 3 - 1 4}$ & $\mathbf{2 0 1 4 - 1 5}$ & $\mathbf{2 0 1 5 - 1 6}$ & $\mathbf{2 0 1 6 - 1 7}$ & $\mathbf{2 0 1 7 - 1 8}$ & $\mathbf{2 0 1 8 - 1 9}$ \\
\hline Chhattisgarh & 1164.05 & 1208.61 & 1231.57 & 1277.32 & 1373.55 & 1469.38 & 1566.88 \\
\hline Goa & 61.24 & 67.81 & 66.6 & 54.34 & 51.36 & 54.88 & 57.17 \\
\hline Gujarat & 10314.63 & 11112.18 & 11690.57 & 12262.35 & 12784.12 & 13569.06 & 14492.77 \\
\hline Madhya Pradesh & 8837.79 & 9599.2 & 10779.07 & 12148.37 & 13445.32 & 14713.17 & 15911.13 \\
\hline Maharashtra & 8733.69 & 9089.03 & 9542.29 & 10152.61 & 10402.15 & 11102.29 & 11655.46 \\
\hline
\end{tabular}

Source: India Stats.com 
International Journal of Social Science and Economic Research

ISSN: 2455-8834

Volume:06, Issue:03 "March 2021"

Figure 7: Milk Production in Northern States from 2012-13 to 2018-19 (figures in 000 tonnes)

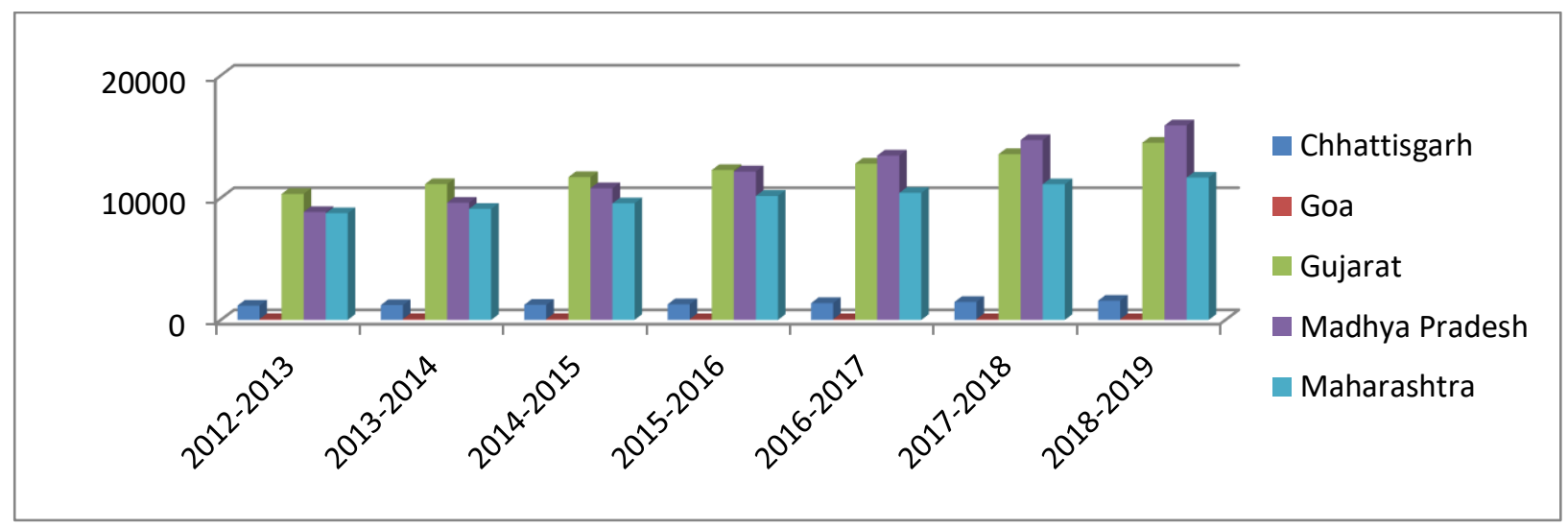

\section{Milk Production in Eastern states}

Table 10 and diagram 8 represents milk production from 2012- 13 to 2018-19 in the Eastern states. Among eastern states, five major milk producing states were chosen for the study. Bihar stands first place in production of milk at all reference period. Its production was

Table 10: Milk Production in Eastern states from 2012-13 to 2018-19 (figures in 000 tonnes)

\begin{tabular}{|c|c|c|c|c|c|c|c|}
\hline East Region & $\mathbf{2 0 1 2 - 1 3}$ & $\mathbf{2 0 1 3 - 1 4}$ & $\mathbf{2 0 1 4 - 1 5}$ & $\mathbf{2 0 1 5 - 1 6}$ & $\mathbf{2 0 1 6 - 1 7}$ & $\mathbf{2 0 1 7 - 1 8}$ & $\mathbf{2 0 1 8 - 1 9}$ \\
\hline Assam & 799.67 & 814.52 & 829.47 & 843.46 & 861.27 & 871.89 & 882.27 \\
\hline Bihar & 6844.84 & 7197.06 & 7774.89 & 8288.42 & 8711.07 & 9241.5 & 9818.1 \\
\hline Jharkhand & 1679 & 1699.83 & 1733.72 & 1812.38 & 1893.8 & 2015.62 & 2183.05 \\
\hline & & & & & & & \\
Odisha & 1724.4 & 1861.19 & 1903.14 & 1930.47 & 2003.42 & 2087.96 & 2311.07 \\
\hline & & & & & & & \\
West Bengal & 4859.23 & 4906.21 & 4961 & 5038.47 & 5182.6 & 5388.61 & 5606.82 \\
\hline
\end{tabular}

Source: India Stats.com 
International Journal of Social Science and Economic Research

ISSN: 2455-8834

Volume:06, Issue:03 "March 2021"

Figure 8: Milk Production in Eastern states from 2012-13 to 2018-19 (figures in 000 tonnes)

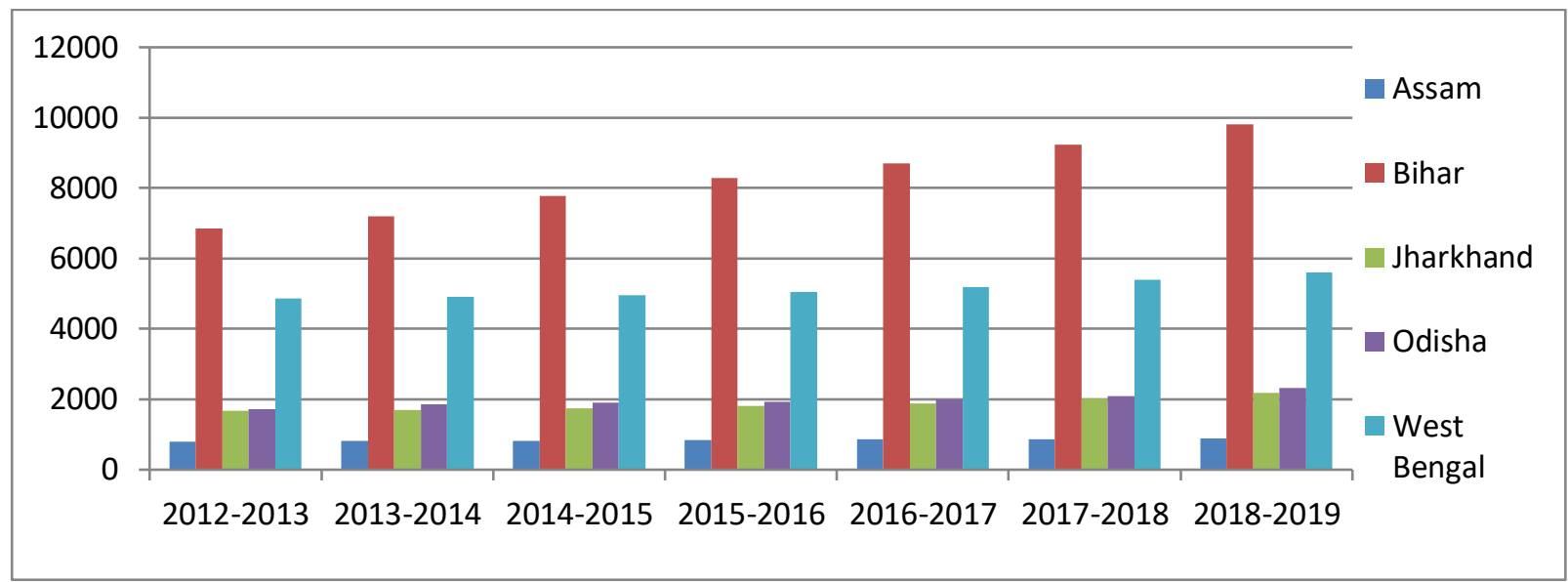

6844.84 thousand tonnes in 2012-13 and rose to 9818.1 thousand tonnes in 2018-19.West Bengal, Odisha and Jharkhand were in second, third and fourth place respectively in production of milk.

Assam is the lowest producer of milk in eastern region. The least milk producing eastern state is Nagaland. Its data indicates declining of production from 78.66 thousand tonnes in 2012-13 to 72.57 thousand tonnes in 2018-19.

State wise analysis of milk production represents that, some states are producing milk on large scale and some on small scale. The factors responsible for large scale production of milk in some states are higher number of buffaloes, cross breed cows, better feeding practices, favourable climate, better health care facilities, high yield per buffaloes and cows, and supportive measures given by the government. In the least milk producing states, low number of bovine population, lack of healthcare, inappropriate feeding, unfavourable climate, lack of infrastructure facilities and support of the government were responsible for low production.

One Way ANOVA Model is used to analyse the difference in milk production between the regions for the period 2012-13 to 2018-19. 
International Journal of Social Science and Economic Research

ISSN: 2455-8834

Volume:06, Issue:03 "March 2021"

Table 11: Descriptive Statistics

\begin{tabular}{|c|c|c|c|}
\hline Regions & N & Mean & Std. Deviation \\
\hline South & 28 & 7268.1929 & 3685.22520 \\
\hline North & 42 & 11380.7076 & 9264.61087 \\
\hline West & 35 & 7201.2003 & 5627.55622 \\
\hline East & 35 & 3616.0120 & 2816.68483 \\
\hline Total & 140 & 7572.1539 & 6783.78656 \\
\hline
\end{tabular}

The table 11 represents the mean and standard deviation value of zone wise milk production for the study period from 2012-13 to 2018-19.

Mean values show that states of north region producing highest 11380.7 million tonnes of milk production followed by states of southern region 7268.2 million tonnes of milk. Western region states producing 7201.2 million tonnes of milk, stands in third place followed by Eastern region states which is least producer of milk. It has produced 3616.01 million tonnes of milk during the study period.

Table 12: Anova Results for Region Wise Milk Production

\begin{tabular}{|l|r|r|r|r|c|}
\hline & \multicolumn{1}{|c|}{ Sum of Squares } & \multicolumn{1}{c|}{ df } & Mean Square & F & Sig. \\
\hline $\begin{array}{l}\text { Between } \\
\text { Groups }\end{array}$ & 1164403691.024 & 3 & 388134563.675 & 10.088 & .000 \\
\hline $\begin{array}{l}\text { Within } \\
\text { Groups }\end{array}$ & 5232342968.352 & 136 & 38473110.061 & & \\
\hline Total & 6396746659.376 & 139 & & & \\
\hline
\end{tabular}

The table 12 represents Anova results for region wise milk production from 2012-13 to 2018-19. The result reveals that the calculated $F$ value is 10.088 and it is statistically significant at 1 percent level. It implies that there is a significant difference in average milk production across regions. 
International Journal of Social Science and Economic Research

ISSN: 2455-8834

Volume:06, Issue:03 "March 2021"

Table 13: Post hoc test for zone wise milk production

\begin{tabular}{|l|l|r|r|r|}
\hline \multirow{3}{*}{ (I) zone } & (J) zone & \multicolumn{1}{|c|}{$\begin{array}{c}\text { Mean Difference } \\
\text { (I-J) }\end{array}$} & \multicolumn{1}{c|}{ Std. Error } & \multicolumn{1}{c|}{ Sig. } \\
\hline \multirow{3}{*}{ South } & North & $-4112.51476^{*}$ & 1513.29643 & 1.000 \\
\cline { 2 - 5 } & West & 66.99257 & 1572.66378 & .098 \\
\cline { 2 - 5 } & East & 3652.18086 & 1572.66378 & .037 \\
\hline & South & $4112.51476^{*}$ & 1513.29643 & .020 \\
\hline North & West & $4179.50733^{*}$ & 1419.59788 & .000 \\
\hline & East & $7764.69562^{*}$ & 1419.59788 & 1.000 \\
\hline & South & -66.99257 & 1572.66378 & .020 \\
\hline West & North & $-4179.50733^{*}$ & 1419.59788 & .078 \\
\hline & East & 3585.18829 & 1482.72163 & .098 \\
\hline & South & -3652.18086 & 1572.66378 & .000 \\
\hline East & North & $-7764.69562^{*}$ & 1419.59788 & .078 \\
\hline & West & -3585.18829 & 1482.72163 & \\
\hline
\end{tabular}

*. The mean difference is significant at the 0.05 level.

Analysis of variance group mean is that, which does not show which group/region is significantly differs with other groups or regions. To know that, the post hoc test has been used. Results of Post hoc test for region wise milk production during 2012-13 to 2018-19 presented in the above table 13. It is clear from the results that, there is a significant difference in the average milk production of south region compared north and east regions. But there is no significant difference in the average milk production between south region and west region. The difference in the average milk production between north region to east region is significant compare with west and south region. The difference in average milk production between west region and north region is significant compared to east region. But there is no significant difference in average milk production between west region and south region. There is a significant difference in average milk production between east region and north region compared with west and south regions.

\section{Conclusion}

India emerged as the largest producer of milk in the world. The result of the dummy reveals that, there is a significant increase in milk production after 1998. Though there is a significant increase in milk production which is not similar across the regions. Uttar Pradesh, Rajasthan, 
Madhya Pradesh, Andhra Pradesh and Gujarat were the top five leading states in production of milk. These states are contributing 53.1 percent to total milk production. Per capita availability of milk, yield per cross breed cows and indigenous cows were increased significantly over a period of time. Dairy cooperatives were playing significant role in mobilising and marketing milk in India. It has resulted in supplementing additional income to small farmers, marginal farmers, and land less labourers and women farmers in rural area. There is a need of encouraging milk rearing activity in the country to support rural livelihood, sustainable agriculture practices, healthy human resource and for better global trade.

\section{Reference}

1. Deepak Shah Indian Dairy industry: Present Status \& Future Prospects, Productivity, Vol. 42, No. 3, October-December, 2001.

2. Deshmukh M S (2014): Growth and Performance of Dairy Sector in India Voice of Research, Vol. 3 Iss. 2, September 2014, ISSN No. 2277-7733 ...39

3. Government of India (2017-18): National Dairy Development Report (NDDB), Annual Report.

4. Government of India (2019): Basic Animal Husbandry Statistics, New Delhi: Department of Animal Husbandry and Dairying, Ministry of Agriculture.

5. India Stats .com 